\title{
Capital Market Development and Financial Openness in Sub-Saharan Africa
}

\author{
Martin Emeka Okafor, Clement Nwakoby, Gideon Kasie Ezu* \\ Department of Banking and Finance, Nnamdi Azikiwe University, Awka, Nigeria \\ Correspondence Author*
}

\begin{abstract}
The inability of capital markets in Sub-Saharan Africa in fund mobilization has affected financial openness in the subcontinent. It has been vigorously argued that financial openness can still thrive without viable capital market but the intermediation function of capital market should not be overlooked. To this end, this study examined the nexus between capital market and financial openness in Sub-Saharan African Countries for 30 years period ranging from 1990 - 2019.The study proxied financial openness with capital account balance ratio, private capital inflow ratio, number of listed companies, external finance through foreign capital market and per capita income ratio while capital market development was measured with market capitalization ratio. The study employed secondary data collected from World Development Indicators, Securities and Exchange Commission statistical bulletin, and Stock Exchange fact books of the respective countries. The study adopted ex-post facto research design while the time series data were analyzed using descriptive statistics, correlation, unit root test, granger causality test, Johansen co-integration and error correction model via E-Views 10 . The result revealed that there is no significant relationship between market capitalization ratio and capital account balance ratio in Nigeria; a significant negative relationship between capital account balance ratio and market capitalization ratio in Zimbabwe; a significant positive relationship between private capital inflow ratio and market capitalization ratio in South Africa and a significant positive relationship between private capital inflow ratio and market capitalization ratio in Nigeria. The study recommended that Sub-Saharan Countries should develop trade openness and liberalisation policy that would promote the international relationships necessary for increasing market opportunities and enhancing profitable investments. Therefore the country should continue to develop its capital market to achieve international standards and attract more investors.
\end{abstract}

Keywords: capitalization, ratio analysis, financial market, per capita income, interest rate.

\section{INTRODUCTION}

$\mathrm{F}$ nancial openness refers to an individual country's approach to foreign investments in corporations within its jurisdiction, to the policies of each country with respect to regulating exports of specified goods and services, and to each government's policy on what is called capital flows (Sahoo \& Sethi, 2020). Financial openness is referred to as the openness of the financial market of a country to other countries. It allows people to trade and carry out various financial transactions in its domestic market, which is called financial market openness and financial transaction admittance. In the same time, it allows residents and domestic institutions participate the transactions in international financial markets (Arif-Ur-Rahman \& Inaba, 2020). Fasanya and Olayemi (2020) assert that that financial openness includes 7 elements: capital account openness, stock market openness, American Depository Receipt (ADR) and national fund issuance, bank reformation, privatization, capital flow and foreign direct investment (FDI).

Several countries, including developing and emerging economies have witnessed some dramatic domestic financial/capital account liberalization in the past decades. The opening of world economies and quest for greater integration also gave impetus for financial liberalization and liberalization of the economies of both developing countries and emerging economies. This is also in line with the "Washington Consensus", which advocated for liberalization of inflows, competitive exchange rate, interest rate liberalization, trade liberalization, privatization, and deregulation of economic activities (Miller, Kim, Roberts, Riley \& Whiting, 2017). Based on models of competitive and efficient markets, economic theory holds that financial openness should foster economic growth and development; empirical works so far have not found indubitable evidence for the existence of such a link. While some countries have benefited from financial liberalization, others have not enjoyed higher economic growth. Some have even experienced some crises and recessions in the years following liberalization (Schmukler \& Abraham, 2017).

Despite the efforts to promote the ideals of financial openness cum capital account openness, private capital inflow, number of listed companies, foreign capital market, external financing, and per capita income in through competitive market framework, there is still the fundamental challenge of understanding its real impact on market capitalization. Thus, this dissertation is to determine the link between financial openness and capital market development using selected SubSaharan African countries as bases for empirical analysis.

\subsection{Statement of the Problem}

One of the major challenges facing private sector in Africa is lack of credit facilities. Investment, growth and economic welfare are also low in developing countries particularly in 
Africa countries (Goh, Tong \& Tang, 2019). Most SubSaharan African countries have recently undergone extensive financial sector reforms. The reform package includes restructuring and privatization of state owned banks, the introduction of private banking systems, along with bank supervisory and regulatory schemes, the introduction of a variety of measures to promote the development of financial markets; including money and stock markets. International organizations like International Monetary Fund (IMF) and World Bank (WB) as part of an effort of financial sector openness are pressuring Sub-Saharan African countries to privatize the state owned banks and establish capital markets so as to integrate with the rest of the world (Cerdeiro \& Komaromi, 2019).

Recent studies have shown mixed results indicating that the nexus between financial openness and capital market development is inconclusive. As far as the empirical works for Sub-Saharan Africa (SSA) are concerned, there is no consensus on the direction of causality between financial openness and capital market development. For instance, Akinlo and Egbetunde, (2010) found a bi-directional causality between financial openness and capital market development. Tsaurai and Odhiambo (2012); Ibrahim and Nuruddeen (2016) found a positive and long relationship between financial openness and capital market development. Akinsola and Odhiambo (2017) found a significant positive relationship between financial openness and stock market development. On the other hand, Orji, Anthony-Orji and Ogbuabor (2016) showed that financial openness contributed both negatively and positively to growth in the short run and long run respectively.

Tsaurai (2016) found a positive but weak uni-directional causality running from financial from financial openness to stock market development; Gentzoglanis (2017) observed a weak negative relationship between financial openness and stock market development. While, Okpara (2010) and Ake and Dehuan (2010) denied the existence a causal relationship between financial openness and capital market development; McLean and Shrestha (2012); Mona (2013); Thiago and Cleiton. (2015) found a negative relationship between financial openness and capital market development. From the foregoing, it is crystal clear that there is a gap in knowledge. In an attempt to closing the gap in knowledge, this study considered two countries each from three (3) Sub-Saharan African regions with a focus on Kenya (for Eastern Africa); Zimbabwe (for Eastern Africa); Botswana (for Southern Africa); South Africa (for Southern Africa); Nigeria (for Western Africa) and Ghana (for Western Africa) which previous studies are yet to explore.

\subsection{Objectives of the Study}

i. Evaluate the relationship between external finance through foreign capital market and market capitalization ratio in Sub-Saharan African Countries. ii. Ascertain the relationship between number of listed companies and market capitalization ratio in Sub-Saharan African Countries.

\subsection{Research Hypotheses}

$\mathrm{Ho}_{\mathrm{l}}$ : There is no significant relationship between external finance through foreign capital market and market capitalization ratio in Sub-Saharan African Countries.

$\mathrm{Ho}_{2}$ : There is no significant relationship between private capital inflow ratio and market capitalization ratio in Sub-Saharan African Countries.

\subsection{Significance Of The Study:}

\section{i. Government}

The Government will use the finding to critically assess the relationship between financial openness and capital market development with a view to finding solution to dwindling capital market position in African Countries. This study would enable the federal government support economic growth by allowing resources to move across borders to their most productive uses. These flows would expand the opportunities for savers and, in the savings-rich countries, would likely raise the return on domestic savings.

\section{ii. Capital Market Regulatory Authority}

The findings of this study will also offer opportunity to capital market regulatory authorities in African Countries to critically face capital market persistent challenges in this era of globalization. It would also provide impetus for institutional reform within countries. Such reforms might include a better legal system to enforce contracts and other property rights, better accounting and disclosure standards as domestic firms compete for foreign funds, and improved prudential supervision as domestic regulators observe the riskmanagement practices of foreign financial institutions.

\section{iii. Investors}

This study would also give local corporate investors, foreign corporate investors and individual investors to understand more about African capital markets with a view to improving their transactions in the market. Again, this study, would enable investors across countries to better absorb economic shocks by allowing temporary current account surpluses and deficits. For example, a spending boom that leads the economy to overheat could induce a rise in the country's currency and a decline in exports, restoring more normal conditions and avoiding an undesirable rise in inflation.

\section{REVIEW OF RELATED LITERATURE}

\subsubsection{Financial Openness}

Financial openness, which can be defined as integration into international financial markets, can cause significant changes 
in countries' production structures and in the methods of doing business through the quantity and quality of international capital flows. (Serdaroğlu, 2015) Almost all countries maintain some level of control over the amount of wealth that can be transferred abroad (e.g. requirements that citizens declare, upon leaving their country for any period of time, whether they are transporting a certain amount of cash), types of investments, corporate mergers and acquisitions that can be carried out by foreign commercial or governmental entities (for example, regulations that require prospective foreign purchases of American businesses that involve the transfer of militarily or commercially-sensitive technologies or "know-how"), and the level of control foreign businesses or governments can exercise over a country's financial institutions, basically, the fewer such regulations or restrictions, the more "open" the country in question (William, 2011).

Financial openness refers to the movement of money across borders without government interference. Such capital flows are very sensitive, as governments which want foreign investment in their own financial sectors may not be as open to reciprocal arrangement that involves capital leaving the country. Such arrangements which, however are often the product of agreements or treaties between governments which share similar ideas on economic growth, as well as on the role of trade and investments in facilitating growth (Ledenyov \& Ledenyov, 2016). Financial openness usually includes an overall absence of government regulation to the ownership of the means of production, government encouragement of private financial interests, and a liberal relationship between businesses and its shareholders (Carmen \& Kenneth, 2010). Financial openness is a reflection of how much a participant or a member nation is in the "globalised" economy (Ledenyov $\&$ Ledenyov, 2016). Financial openness is probably one of the best makers related to whether or not a nation is a part of the global economy because its ability to trade and engage in commercial growth with any other nation (Kannan, 2018). Given the global marketplace, financial openness is a very good indicator of how involved a nation is in it.

\subsubsection{Capital Market Development}

A capital market development is the institutional frameworks through which the capital functions in any country (Wu \& Xia, 2016). The main objectives of developing a country's capital market is to mobilize savings from numerous economic units in the country for economic growth and development, provide adequate liquidity to investors and to broaden the ownership base of assets as well as the creation of a buoyant private sector (Quinn \& Toyoda, 2018): Capital market development entails the efforts to improve the macroeconomic environment and reform the institutions believed to foster financial development (China \& Ito, 2018): The failure to develop an efficient capital markets may have important consequences, as growing empirical evidence suggests that financial development is not just correlated with a healthy economy, but actually caused economic growth and has a positive impact on poverty alleviation and income distribution as well. The development of capital markets in rich countries has been accompanied by an increasing financial integration across nations, increasing use of capital markets, capital flows, private capital flows (Eichengreen \& Andrew, 2014; Jahan \& Wang, 2016; Horn \& Narita, 2019).

\subsection{Theoretical Framework}

\subsubsection{Dependency Theory}

The dependency theory, introduced by Raul Prebisch in the late 1950s, is an economic concept that identifies a financial dependence between the rich and the poor nations (Harvold, 2017). More specifically, this theory holds that the richer nations increase in wealth at the expense of the poorer nations due to a relationship that exists between economic and other factors. Initially, Prebisch, as Director of the United Nations Economic Commission for Latin America, was concerned about the fact that industrialized countries were achieving economic growth, yet without contributing to growth to poor countries (Grinin, Korotayev \& Tausch, 2016; Cesaratto, 2015). Instead, according to Prebisch's studies, the economic activity in the industrialized countries caused a range of economic problems in the poorer nations. Prebisch attributed the situation to the fact that the poorer nations are primarily exporters of commodities and importers of the finished goods that the industrialized nations produce with these commodities. Therefore, it is impossible to achieve equal growth (Garcia-Arias, Fernandez-Huerga \& Salvador, 2013).

Dependency theory became popular in the 1960's as a response to research by Raul Prebisch. Prebisch found that increases in the wealth of the richer nations appeared to be at the expense of the poorer ones. In its extreme form, dependency theory is based on a Marxist view of the world, which sees globalization in terms of the spread of market capitalism, and the exploitation of cheap labour and resources in return for the obsolete technologies of the West. The dominant view of dependency theorists is that there is a dominant world capitalist system that relies on a division of labour between the rich 'core' countries and poor 'peripheral' countries. Over time, the core countries will exploit their dominance over an increasingly marginalized periphery (Cypher, 2013).

Dependency theory advocated an inward looking approach to development and an increased role for the state in terms of imposing barriers to trade, making inward investment difficult and promoting nationalization of key industries. The dependency theory is a characterization of the international system as comprising of a dominant and a dependent state, where the dominant states are the industrialized nations belonging to the OECD (Organization for Economic Cooperation and Development), and the dependent states are the 
states of Latin America, Africa, and Asia, which rely on the export of their commodities to the OECD nations to raise their GDP.

Second, unlike what many people believe, the dependency theory was not critical against imperialism. Instead, it sought to find the connecting dots between the richer and the poorer nations, so that the latter can improve their quality of living. To that end, the dependence theory advocated an increased role of the state to promote the nationalization of domestic industries and protect them from foreign competition (Amadi, 2012; Boianovsky \& Ricaedo, 2014).

\subsection{Empirical Review}

Andrianaivo and Yartey (2009) examined empirically the determinants of financial market development in Africa with an emphasis on banking systems and stock markets. Panel data techniques were used to study the main determinants of banking sector development in Africa. The estimation sample comprises 53 African countries and covered the period 1990 to 2006.The results showed that income level, creditor rights protection, financial repression, and political risk are the main determinants of banking sector development in Africa, and that stock market liquidity, domestic savings, banking sector development, and political risk are the main determinants of stock market development. The study also found that liberalizing the capital account promotes financial market development only in countries with high incomes, welldeveloped institutions, or both. The powerful impacts of political risk on both banking sector and stock market development suggested that resolution of political risk may be important to the development of African financial markets.

Okpara (2010) analyzed the effect of financial liberalization on selected macroeconomic variables namely, Gross Domestic Product (GDP), foreign direct investment, financial deepening, savings and inflation rate in Nigeria from 1989 to 2009. To carry out this analysis, the study employed three alternate methods the parametric paired sample statistic for ttest and the non parametric Wilcoxon signed rank test to determine whether significant differences exists between pre/post liberalization macroeconomic variables. The third method, the discriminant analysis was meant to determine the direction as well as the magnitude of the discriminant variables. The result showed that while real GDP recorded (highest) positive and significant contribution, national savings and foreign direct investment made negative and significant contribution. Financial deepening and inflation rate did not discriminate significantly between non financial and financial liberalization. In the light of this, coupled with the theoretical evidence of bank crisis emanating from financial liberalization, the recommendation that government embarking on financial liberalization should set up an agency that will follow up action, was made.
Ake and Ognaligui (2010) examined the causality relationships between stock markets and economic growth in Cameroon based on the time series data from 2006 to 2010 using Augmented Dickey Fuller Test and Error Correction Model. The findings suggest that the Douala Stock Exchange still doesn't affect Cameroonian economic growth. Research has been made in this topic and found positive relationship between financial stock market development and economic growth, but in Cameroon the purpose of the government to develop economy, by creating the Douala Stock Exchange is still not reached. After running variance decomposition test of Cholesky, the study found systematic evidence that the market capitalization affects positively the GDP. The study came up with the opportunity given to the Cameroonian government to understand that it is time to find financial policies, to encourage companies and develop financial stock market culture, and enhance to push companies to initiate IPO instead of bank loans when money is needed to increase their investment.

Akinlo and Egbetunde, (2010) demonstrated that a causal relationship between financial development and economic growth in Cameroon from 1990-2010 has been argued, in the literature, along the following three possibilities: Financial deepening promotes economic growth (i.e. the finance-led growth hypothesis); Economic growth stimulates financial development (i.e. the growth driven finance hypothesis); Financial development and economic growth influence each other (i.e. the two-way causal relationship that is termed feedback effect or a bi-directional causality).

Balogun (2011) examined the capital market in Nigeria in historical perspective and how this institution has evolved to impact upon the Nigerian economy. The Nigerian capital market is principally a market for long-term investments where corporate equities and long-term debt securities are issued and traded. It is a market that is regulated by the Securities and Exchange Commission (SEC), which is the apex regulatory body of the Nigerian Capital Market. The capital market is so vital to the development of any economy that no country can risk its existence without putting in place measures to regulate the activities of the market.

Zivengwa, Mashika, Bokosi and Makova (2011) explored the causal link between stock market development and economic growth in Zimbabwe using annual time series data for the period 1980 to 2008 . The study evaluated the nature of the relationship between stock market development and economic growth in Zimbabwe. The stock market development was measured using two variables namely stock market size as measured by stock market capitalization as a ratio of GDP and stock market turnover as measured by the value of stocks traded as a ratio of stock market capitalisation. The study utilised advanced econometric techniques of Unit Root Tests, Vector Autoregressive (VAR) and Granger Causality Tests to explore the relationships. The empirical results showed a uni- 
directional causal link that runs from stock market development to economic growth and there is evidence of an indirect transmission mechanism through the effect of stock market development on investment.

Odhiambo (2011) examined the dynamic causal relationship between stock market development and economic growth in South Africa using the newly developed ARDL-Bounds testing procedure. The study used three proxies of stock market development, namely stock market capitalization, stock market traded value and stock market turnover, against real GDP per capita, a proxy for economic growth. Using the 1971-2007 data sets, the empirical results of this study showed that the causal relationship between stock market development and economic growth is sensitive to the proxy used for measuring the stock market development. When the stock market capitalization is used as a proxy for stock market development, the economic growth was found to Grangercause stock market development. However, when the stock market traded value and the stock market turnover are used, the stock market development seems to Granger-cause economic growth. Overall, the study finds the causal flow from stock market development to economic growth to predominate. The results apply irrespective of whether the causality is estimated in the short-run or in the long-run.

Hamid and Sumit (2011) examined economic growth against stock market development in Egypt over a period of 21 years covering 21 emerging markets in a bid to find a relationship between the two. The study used a dynamic panel method and found that there is indeed a positive relationship between the two for a number of stock market indicators and that the relationship is both direct and indirect. They study also found that the indicators may either boost growth in the economy directly or indirectly through the involvement of private investment.

Tsaurai and Odhiambo (2012) studied the dynamics of capital market development in Zimbabwe. The study took stock of the achievements, the trends, as well as the challenges facing the stock market development in Zimbabwe. Apart from highlighting the role of stock market development, as well as the efficacy of the stock market in bolstering economic growth in Zimbabwe, the study also pinpoints some of the factors that limit the stock market development in Zimbabwe. The findings of this study show that the experience of Zimbabwe with stock market development, just as in many other developing countries, is mixed. In particular, the positive influence of stock market development on savings and investment remains low in Zimbabwe. While stock market development has been increasing, the country's gross domestic savings and investment have been low and subsiding. This suggested that Zimbabwe's gross national savings could be stock market development inelastic.

\section{METHODOLOGY}

\subsection{Research Design}

Ex-post facto research design was employed in this study to explore the relationship between financial openness and capital market development with focus on six (6) Sub-Sahara African countries. Ex-post facto or after the fact design attempts to identify a natural impetus for specific outcomes without actually manipulating the independent variable (Onwumere, 2009). With ex-post facto, attempts were made to explain a consequence based on antecedent conditions, determine the effect of a variable on another variable and test a claim using statistical hypothesis testing technique.

\subsection{Population of the Study}

The population of this study consists of the capital markets of the cross section of the three (3) Sub-Saharan African regions. The countries for each region would include Kenya (for Eastern Africa); Zimbabwe (for Eastern Africa); Botswana (for Southern Africa); South Africa (for Southern Africa); Nigeria (for Western Africa); Ghana (for Western Africa). This study would cover 30years time series data period of 1990 - 2019 for the cross section of 6 Sub-Saharan African Countries. 1990 is chosen as the base year based on the fact that countries in Sub-Saharan Africa under study established their capital markets on or before 1990 and the implementation of financial liberalization and other economic reforms became effective in 1990.

\subsection{Sample Size and Sampling Method}

Three (3) Sub-Saharan African countries were purposively selected with the adoption of purposive sampling method, based on a country's stock exchange that was established on or before 1990 and whose data set would be complete and available for the study period (1990-2019). However, three (3) countries which include South Africa, Nigeria and Zimbabwe were sampled for this study.

\subsection{Sources of Data}

This study made use of secondary data precisely. The data for capital account balance ratio, private capital inflow ratio, number of listed companies, external finance through foreign capital market and per capita income ratio were obtained from World Development Indicators and the respective countries' stock exchange fact books. While the data for market capitalization ratios were sourced from the respective countries' stock exchange fact books and central bank statistical bulletin.

\subsection{Model Specification}

This study adapted a model used by Veron (2009).

$\mathrm{SD}=\alpha+\alpha_{1} \mathrm{GDPPC}+\alpha_{2} \mathrm{INF}+\alpha_{3} \mathrm{ER}+\alpha_{4} \mathrm{BANK}+\mu$

Specifically, the above equation would be re-constructed as: 


\begin{tabular}{|c|c|c|c|}
\hline$C \mathrm{R}_{\mathrm{it}}=\beta_{0}+\beta_{1} \mathrm{C}$ & - & & \\
\hline $\mathrm{CR}_{\mathrm{it}}=\beta_{0}+\beta_{1} \mathrm{PCAPIR}_{\mathrm{it}}+\mu_{\mathrm{it}}$ & - & - & \\
\hline $\mathrm{CR}_{\mathrm{it}}=\beta_{0}+\beta_{1} \mathrm{NLC}_{\mathrm{it}}+$ & - & & \\
\hline$=\beta_{0}+\beta_{1} \mathrm{EFCM}_{\mathrm{it}}+\mu_{\mathrm{it}}$ & - & & \\
\hline $\mathrm{CR}_{\mathrm{it}}=\beta_{0}+\beta_{1} \mathrm{PCIR}_{\mathrm{it}}+\mu_{\mathrm{it}}-$ & - & - & - \\
\hline
\end{tabular}

Where:

$\mathrm{MCR}_{\mathrm{it}}=$ Market Capitalization Ratio of country $\mathrm{i}$ in period $\mathrm{t}$ (dependent variable)

$\mathrm{CABR}_{\mathrm{it}}=$ Capital Account Balance Ratio of country $i$ in period $t$ (explanatory variable)

PCAPIR $_{\text {it }}=$ Private Capital Inflow Ratio of country $i ́$ in period $\mathrm{t}$ (explanatory variable)

$\mathrm{NLC}_{\mathrm{it}}=$ Number of Listed Companies of country $i$ in period $\mathrm{t}$ (explanatory variable)

$\mathrm{EFCM}_{\mathrm{it}}=$ External Finance through Foreign Capital Market of country $i$ in period $t$ (explanatory variable)
$\mathrm{PCIR}_{\mathrm{it}}=$ Per capita Income Ratio of country $\mathrm{i}$ in period $\mathrm{t}$ (explanatory variable)

$\mu_{\mathrm{it}}=$ error term that are not captured in the model of country $i$ in period $\mathrm{t}$

$\beta_{0}=$ constant term (Intercept)

$\beta_{1}=$ coefficients to be estimated

$i=$ individual countries

$\mathrm{t}=$ time periods

\subsection{Decision Rule}

Accept the alternative hypothesis, if the P-value of the test is less than 0.05. Otherwise accept Ho.

\section{DATA PRESENTATION}

Table 4.1: ADF (Augmented Dickey Fuller) Unit Root Test Result (South Africa)

\begin{tabular}{|c|c|c|c|c|c|c|}
\hline Variables & Test Statistic & \multicolumn{3}{|c|}{ Test Critical Values } & Status & Prob. \\
\hline & ADF & $1 \%$ level & $5 \%$ level & $10 \%$ level & Stationary & \\
\hline MCR & -6.709049 & -3.711457 & -2.981038 & -2.629906 & $1(1)$ & 0.0000 \\
\hline CABR & -3.995283 & -3.788030 & -3.012363 & -2.646119 & $1(1)$ & 0.0064 \\
\hline PCAPIR & -5.356579 & -3.724070 & -2.986225 & -2.632604 & $1(1)$ & 0.0002 \\
\hline NLC & -5.063109 & -3.699871 & -2.976263 & -2.627420 & $1(1)$ & 0.0003 \\
\hline EFCM & -6.700507 & -3.711457 & -2.981038 & -2.629906 & $1(1)$ & 0.0000 \\
\hline PCIR & -5.204305 & -3.711457 & -2.981038 & -2.629906 & $1(1)$ & 0.0003 \\
\hline
\end{tabular}

Source: E-Views 10 output file, 2021

Table 4.2 Descriptive Statistics (Nigeria)

\begin{tabular}{|c|c|c|c|c|c|c|}
\hline & CABR & PCAPIR & NLC & EFCM & PCIR & MCR \\
\hline Mean & 5.796000 & 1.931333 & 2.087000 & 1.834667 & 3.048333 & 1.147333 \\
\hline Median & 3.950000 & 1.925000 & 2.150000 & 1.830000 & 3.160000 & 1.100000 \\
\hline Maximum & 9.870000 & 2.130000 & 2.340000 & 2.230000 & 3.510000 & 1.700000 \\
\hline Minimum & 1.000000 & 1.640000 & 1.790000 & 1.370000 & 2.430000 & 0.400000 \\
\hline Std. Dev. & 2.976017 & 0.135564 & 0.200760 & 0.207476 & 0.341024 & 0.277898 \\
\hline Skewness & 0.010767 & -0.248218 & -0.287871 & -0.239388 & -0.244626 & -0.068932 \\
\hline Kurtosis & 1.278699 & 2.285493 & 1.433961 & 2.663847 & 1.519732 & 3.688083 \\
\hline Jarque-Bera & 18.04178 & 0.946211 & 9.479945 & 0.427781 & 23.08201 & 0.615582 \\
\hline Probability & 0.000000 & 0.623064 & 0.000025 & 0.807437 & 0.000000 & 0.735069 \\
\hline Sum & 13.78800 & 57.94000 & 32.61000 & 55.04000 & 91.45000 & 34.42000 \\
\hline Sum Sq. Dev. & 256.8437 & 0.532947 & 1.168830 & 1.248347 & 3.372617 & 2.239587 \\
\hline Observations & 30 & 30 & 30 & 30 & 30 & 30 \\
\hline
\end{tabular}

Source: E-Views 10, Descriptive Output 2021

From table 4.2, the standard deviations in the study for the period 1990-2019 are 2.976, 0.136, 0.201, 0.207, 0.341 and 0.278 for CABR, PCAPIR, NLC, EFCM, PCIR and MCR respectively. For such distributions, it is the case that $297.6 \%$, $13.6 \%, 20.1 \%, 20.7 \%, 34.1 \%$ and $27.8 \%$ of values are less than one standard deviation (1SD) away from the mean values 
of CABR, PCAPIR, NLC, EFCM, PCIR and MCR respectively. Skewness and Kurtosis are contained in JarqueBera. Positively skewed is an indication of a rise in revenue while negatively skewed is an indication of loss or backwardness. It is delineated in table 4.6 that all the study variables are negatively skewed with the exception of CABR. Jarque-bera is used to test for normality; to know whether data are normally distributed. Table 4.6 shows that all the data are positively skewed since the Jarque-bera values for the variables are positive. Table 4.6 also reveals that CABR, NLC, and PCIR with probability values of $0.0000,0.0000$, and 0.0000 respectively are less than $5 \%$. So invariably, they are significantly normally distributed. While the probability values for PCAPIR, EFCM and MCR are not significantly normally distributed because their probability values of 0.623 , 0.807 and 0.735 are greater than $5 \%$.

\section{Test of Hypotheses}

\section{Test of Hypothesis I}

$\mathrm{Ho}_{1}$ : There is no significant relationship between external finance through foreign capital market and market capitalization ratio in Sub-Saharan African Countries.

$H a_{1}$ : There is a significant relationship between external finance through foreign capital market and market capitalization ratio in Sub-Saharan African Countries.

Table 4.3: Ordinary Least Square regression analysis testing the relationship between FCM and MCR in Nigeria

\begin{tabular}{|c|c|c|c|c|}
\hline \multicolumn{3}{|c|}{ Dependent Variable: FCM } & & \\
\hline \multicolumn{5}{|c|}{ Method: Least Squares } \\
\hline \multicolumn{5}{|c|}{ Date: $29 / 11 / 21$ Time: $13: 46$} \\
\hline \multicolumn{5}{|c|}{ Sample: 19902020} \\
\hline \multicolumn{5}{|c|}{ Included observations: 30} \\
\hline Variable & $\begin{array}{c}\text { Coefficie } \\
n t\end{array}$ & Std. Error & $\begin{array}{c}\mathrm{t}- \\
\text { Statistic }\end{array}$ & Prob. \\
\hline $\mathrm{C}$ & 2.347898 & 0.056749 & $\begin{array}{c}41.3733 \\
7 \\
\end{array}$ & 0.0000 \\
\hline FCM & 0.010274 & 0.009185 & $\begin{array}{c}11.1863 \\
5\end{array}$ & 0.0000 \\
\hline R-squared & 0.342779 & \multicolumn{2}{|c|}{ Mean dependent var } & 2.291587 \\
\hline Adjusted R-squared & 0.318593 & \multicolumn{2}{|c|}{ S.D. dependent var } & 0.144120 \\
\hline S.E. of regression & 0.143500 & \multicolumn{2}{|c|}{ Akaike info criterion } & -0.980629 \\
\hline Sum squared resid & 0.576579 & \multicolumn{2}{|c|}{ Schwarz criterion } & -0.887216 \\
\hline Log likelihood & 16.70944 & \multicolumn{2}{|c|}{ Hannan-Quinn criter. } & -0.950745 \\
\hline F-statistic & 22.21343 & \multicolumn{2}{|c|}{ Durbin-Watson stat } & 1.679586 \\
\hline Prob(F-statistic) & 0.000000 & & & \\
\hline
\end{tabular}

Source: E-Views 10 Regression Output, 2021

\section{Interpretation of Regression Coefficient Result}

The following regression equation was obtained from table 4.3:

\section{$\mathrm{DMCR}=2.347898+0.010274 \mathrm{DCABR}$}

Using the above model, it is possible to determine the relationship between DMCR and DCABR. Holding all other factors constant, an increase in one unit of the independent variable $(\mathrm{CABR})$ results into a corresponding increase in one unit of MCR, this means that a positive relationship exists between the explanatory variable (CABR) and MCR. The slope coefficient shows that the probability value: $\mathrm{P}\left(\mathrm{x}_{1}=0.0000<0.05\right)$ is less than the critical $\mathrm{P}$-value of 0.05 . This implies that CABR has a significant positive relationship with MCR at 5\% significant level. Results in table 4.10 also indicated that the R-squared for the model is 0.34 , meaning that the regression model used for this study is a good predictor. The independent variable explained $34 \%$ of the variation in MCR. Only $66 \%$ of variation in MCR is not explained by the regression model. The Durbin-Watson value of 1.679586 indicates the absence of serial correlation in the model.

\section{Decision:}

The P-Value of the test Prob(F-statistic) $=0.000000$ is less than the $\alpha$-value of 0.05 ; therefore $\mathrm{H}_{1}$ is accepted and Ho is rejected. Since the p-value of the test is less than 0.05 , then there exists enough evidence to reject the null hypothesis and conclude that There is a significant relationship between external finance through foreign capital market and market capitalization ratio in Sub-Saharan African Countries.

Table 4.4: Granger Causality Test showing the Causality between CABR and MCR in Nigeria

\begin{tabular}{|l|l|l|l|}
\hline \multicolumn{2}{|l|}{ Pairwise Granger Causality Tests } \\
\hline \multicolumn{2}{|l|}{ Date: 29/11/21 Time: 13:48 } & \\
\hline \multicolumn{2}{|l|}{ Sample: 19902020} & & \\
\hline Lags: 2 & $\begin{array}{l}\text { Ob } \\
\text { s }\end{array}$ & F-Statistic & Prob. \\
\hline Null Hypothesis: & 28 & 7.32350 & 0.0076 \\
\hline $\begin{array}{l}\text { CABR does not Granger Cause } \\
\text { MCR }\end{array}$ & 28.97268 & 0.3931 \\
\hline MCR does not Granger Cause CABR & 0.96 \\
\hline
\end{tabular}

Source: E-Views 10 Causality Output, 2021

Decision Rule:

If the F-value of the causality test is statistically significant at $5 \%$, then causality is established. This implies that the Independent variable granger causes the dependent variable. Hence, $\mathrm{H}_{1}$ is accepted, otherwise accept Ho.

\section{Interpretation of Diagnostic Result}

The results of the Granger causality test in table 4.4 indicates a uni-directional relationship between MCR and CABR at $5 \%$. It implies that CABR granger causes $\mathrm{MCR}$ at the Probability value of 0.0076 , the causation runs from CABR to MCR at 5\% level of significance and does not run in the reverse sense. The Granger Causality test result reveals 
evidence of casual relationship between CABR and MCR, thereby confirming the hypothesis that CABR has a statistically significant relationship with MCR in South Africa.

\section{Test of Hypothesis II}

$\mathrm{Ho}_{2}$ : There is no significant relationship between private capital inflow ratio and market capitalization ratio in SubSaharan African Countries.

$\mathrm{Ha}_{2}$ : There is a significant relationship between private capital inflow ratio and market capitalization ratio in Sub-Saharan African Countries.

Table 4.5: Ordinary Least Square regression analysis testing the relationship between PCAPIR and MCR in South Africa

\begin{tabular}{|c|c|c|c|c|}
\hline \multicolumn{4}{|c|}{ Dependent Variable: DMCR } & \\
\hline \multicolumn{4}{|c|}{ Method: Least Squares } & \\
\hline \multicolumn{4}{|c|}{ Date: 29/11/21 Time: 15:12 } & \\
\hline \multicolumn{4}{|c|}{ Sample (adjusted): 1991 2020 } & \\
\hline Included observations: 30 after adjustments & Prob. \\
\hline Variable & $\begin{array}{c}\text { Coefficie } \\
\text { nt }\end{array}$ & Std. Error & $\begin{array}{c}\text { t- } \\
\text { Statistic }\end{array}$ & 0.2564 \\
\hline C & 0.014793 & 0.012759 & $\begin{array}{c}1.15939 \\
1\end{array}$ & 0.0002 \\
\hline $\begin{array}{c}\text { DPCAPIR } \\
\text { R-squared }\end{array}$ & 0.044573 & 0.383556 & Mean dependent var & 0.016207 \\
\hline $\begin{array}{c}\text { Adjusted R- } \\
\text { squared }\end{array}$ & 0.362608 & S.D. dependent var & 0.067634 \\
\hline $\begin{array}{c}\text { S.E. of } \\
\text { regression }\end{array}$ & 0.068059 & Akaike info criterion & -2.470405 \\
\hline $\begin{array}{c}\text { Sum squared } \\
\text { resid }\end{array}$ & 0.125066 & \multicolumn{2}{|c|}{ Schwarz criterion } & -2.376108 \\
\hline Log likelihood & 37.82087 & \multicolumn{2}{|c|}{ Hannan-Quinn criter. } & -2.440872 \\
\hline $\begin{array}{c}\text { F-statistic } \\
\text { Prob(F-statistic) }\end{array}$ & 12.65136 & \multicolumn{2}{|c|}{ Durbin-Watson stat } & 1.535724 \\
\hline
\end{tabular}

Source: E-Views 10 Regression Output, 2021

\section{Interpretation of Estimated Regression Coefficients}

The relationship between private capital inflow ratio and market capitalization ratio in South Africa was evaluated based on the result of table 4.5. From table 4.5, PCAPIR with a positive co-efficient of 0.044573 has a significant effect on MCR as indicated by the t-statistic of 3.807071 and its associated probability value of 0.0002 . The $\mathrm{R}$ squared which examines the extent to which the predictors combine to explain the variations in the dependent variable (MCR) shows that the R Squared figure of 0.38 indicates that, reliance on this model will account for $38 \%$ of the variations in the dependent variable (MCR). The Durbin-Watson value of 1.535724 buttressed the fact that the model does not contain auto-correlation, thereby, making the regression fit for prediction purpose. The analysis resulted in F-value of 12.65136 with corresponding p-value of 0.000219 .

\section{Decision}

Since the p-value of the test at 0.000219 is less than the critical significant value of $0.05(5 \%)$, thus $\mathrm{H}_{1}$ is accepted and Ho rejected. This implies that private capital inflow ratio has a significant positive relationship with market capitalization ratio in South Africa at 5\% level of significance.

\section{Findings}

Based on the analysis of this study, the following findings were deduced:

1. There is no significant relationship between external finance through foreign capital market and market capitalization ratio in Sub-Saharan African Countries.

2. There is no significant relationship between private capital inflow ratio and market capitalization ratio in Sub-Saharan African Countries.

\section{CONCLUSION}

This study examined the nexus between financial openness and capital market development in selected Sub-Saharan African Countries for 30 years period ranging from 1990 2019. Existing literature shows that researchers are yet to reach a consensus about the effect of financial openness and capital market development. Therefore, the effect is yet to be well established. In order to avoid spurious estimates, the unit roots of the series were verified using Augmented DickeyFuller (ADF) technique after which Granger Causality, Johansen Co-integration Test and Error Correction Estimates were conducted. Data analysis revealed that there is a significant positive relationship between capital account balance ratio and market capitalization ratio in South Africa; no significant relationship between capital account balance ratio and market capitalization ratio in Nigeria; a significant negative relationship between capital account balance ratio and market capitalization ratio in Zimbabwe; a significant positive relationship between private capital inflow ratio and market capitalization ratio in South Africa; a significant positive relationship between private capital inflow ratio and market capitalization ratio in Nigeria;

\section{RECOMMENDATIONS}

Based on the conclusion and findings of this study, the following were suggested:

i. Sub-Saharan Countries should develop trade openness and liberalisation policy that would promote the international relationships necessary for increasing market opportunities and enhancing profitable investments. Therefore the country should continue to develop its capital market to achieve international standards and attract more investors.

ii. Private sector funding is necessary to sustain the countrys' ongoing efforts in economic diversification 
and citizen empowerment. Financial markets should help to finance local economic projects and therefore the country's financial flow channels should be open enough to transfer savings into investments rather than accumulating deposits.

\section{REFERENCES}

[1] Abedana, V.N., \& Gayomey, J. (2016). IFRS/IAS adoption and its tax challenges and management - views from Ghana. The International Journal of Business Management 4(5), 197-210.

[2] Abedian, I. (2005). Fiscal and monetary policy management in South Africa 1994-2005. Pan African Investment and Research Services. Johannesburg, South Africa.

[3] Brownbridge, M. \& Gockel, A.F. (1996). The Impact of Financial Sector Policies on Banking in Ghana. Research Department of Bank of Ghana

[4] Bryant, M. (2017). Taking stock: Johannesburg Stock Exchange the first 100 years. Johannesburg: Jonathan Ball.

[5] BSE (2013) Annual Report. Botswana Stock Exchange, Gaborone.

[6] Bulut, U. (2017). Financial conditions index as a leading indicator of business cycles in Turkey. In Ü. Hacioğlu \& H. Dinçer (Eds.), Global financial crisis and its ramifications on capital markets (pp. 225-239). Cham: Springer International Publishing.10.1007/978-3-319-47021-4

[7] Bundoo, S.K. (2017). Stock market development and integration in SADC (Southern African Development Community). Review of Development Finance, 7(1), 64-72

[8] Calvo G., Leiderman, L., \& Reinhart, C. (2013). Capital flows and real exchange rate appreciation in Latin America, IMF Staff Papers, 40(1), 108-151.

[9] Carmen, R., \& Kenneth, R. (2010). This time is different: Eight centuries of financial folly. Princeton University Press. 66, 92-94.

[10] CBN, (2006). Central Bank of Nigeria annual report and statement of accounts. http://www.cenbank.org/out/publications/reports/rd/2002/areport02.pdf.

[11] Cerdeiro, D.A., \& Komaromi, A. (2019). Financial openness and capital inflows to emerging markets: In search of robust evidence. IMF Working Paper, WP/19/194.

[12] Dozie, P.G. (2015). Investing in the Nigerian stock market through the Nigerian stock exchange. A Paper Presented at the First Africa Europe Forum "Lets Trust Africa" at UNSCO Headquarters Paris, March 27-30.

[13] Ductor, L., \& Grechyna, D. (2015). Financial development, real sector, and economic growth. International Review of Economics \& Finance, 37, 393-405.

[14] Dzikiti, W. (2017). Banking sector, stock market development and economic growth in Zimbabwe: A multivariate causality framework. Thesis submitted University of South Africa, 1-124,

[15] Edwards, S., \& Tavlas, G. (2014). The order of liberalization of the external sector in developing countries. International Finance Section, Department of Economics, Princeton University.

[16] Eichengreen, B., \& Andrew, R. (2014). Capital controls in the 21st century. Journal of International Money and Finance, 48, 1-16.

[17] Fasanya, I.O., \& Olayemi, I.A. (2020). Modelling financial openness growth-nexus in Nigeria: Evidence from bounds testing to cointegration approach. Futur Bus J 6, 4 (2020). https://doi.org/10.1186/s43093-019-0008-2
[18] Fasanya, O.I., Onakoya, A., \& Ofoegbu, I.D. (2013). Capital Market Development: A Spur to Economic Growth in Nigeria. Acta Universitatis Danubius. Economica, 9(5), 245-255.

[19] Filler, R.K., Jan, H., \& Nauro, F.C. (2009). Do stock market promote economic growth?, The William Davidson Institute (University of Michigan Business School). Working Paper Series, No. 267, September.

[20] Gosh, A.R., Ostry, J.D., \& Qureshi, M.S. (2018). Taming the tide of capital flows: A policy guide. MIT Press.

[21] Goyal, A. (2012). The future of financial liberalization in South Asia. Asia pac. Dev. J. 19(1), 63-95.

[22] Hsiao, C. (2009). Panel data analysis - advantages and challenges. Los Angeles: University of Southern California.

[23] Ibrahim, S.S., \& Nuruddeen, T. (2016). The linkages between trade openness, financial openness and economic growth in Nigeria. $\quad$ https://www.researchgate.net/publication/319352421. Retrieved 14-4-2018.

[24] Jugurnath, B., Chuckun, N., \& Fauzel, S. (2016). Foreign direct investment \& economic growth in Sub-Saharan Africa: an empirical study. Theoretical Economics Letters, 6(4), 798-807.

[25] Kannan, A. (2018). What is financial openness? https://www.enotes.com/homework-help/what-financial-openness181567.

[26] Korinek, A. (2018). Regulating capital flows to emerging markets: An externality view. Journal of International Economics, 111(61), 80.

[27] Lane, P.R., \& Milesi-Ferretti, G.M. (2020). The external wealth of nations mark II: Revised and extended estimates of foreign assets and liabilities, 19702004. Journal of International Economics, 73(2), 223-250.

[28] Levine, R., \& Zervos, S. (2016). Stock market development and long-run growth. World Bank Economic Review, 10, 323-339.

[29] Nowbutsing, B. M. (2014). The impact of openness on economic growth: Case of Indian Ocean rim countries. Journal of Economics and Development Studies, 2(2), 407-427.

[30] Omole, D.A., \& Falokun, G.O. (2009). The impact of interest rate liberalization on corporate financing strategies of quoted companies in Nigeria. Proceedings of the Conference on African Economic Research Consortium, (AERC'09), Kenya, pp: 52-52.

[31] Patrick, H.T. (2016). Financial development and economic growth in underdeveloped countries. Economic Development and Cultural Change, 14(1), 174-189.

[32] Quinn, D., \& Toyoda, A.M. (2018). Does capital account liberalization lead to growth. Review of Financial Studies, 21,1403-1449.

[33] Rachdi, H., \& Mensi, S. (2012). Does institutions quality matter for financial development and economic growth nexus? Another look at the evidence from Mena countries. Economic Research Forum, Working Paper 705.

[34] Sabandi, M., \& Noviani, L. (2015). The effects of trade liberalization, financial development and economic crisis on economic growth in Indonesia. Journal of Economics and Sustainable Development, 6(24), 120-128.

[35] Shaw, E. (1973). Financial deepening in economic development. New York: Oxford University Press.

[36] Woodruff, J. (2019). How to calculate a working capital balance sheet. https://smallbusiness.chron.com/calculate-working-capitalbalance-sheet-11175.html. Retrieved 17/04/2020

[37] Zulfiqar, K. \& Kausar, R. (2012). Trade liberalization, exchange rate and export growth in Pakistan. Far East Journal of Psychology and Business, 9(2), 32-47. 